\title{
ANALYSIS OF SOCIAL INTERACTION OF MENTALLY RETARDED CHILDREN
}

\author{
Yudhie Suchyadi ${ }^{1)}$, Yulia Ambarsari ${ }^{1)}$, Elly Sukmanasa ${ }^{1)}$ \\ ${ }^{1)}$ Universitas Pakuan, Bogor, Indonesia \\ Corresponding Author: ydhie.schyadi@gmail.com
}

\begin{abstract}
Differences in the characteritics of children with special needs will require the ability of teachers to combine various abilities and talents of each child, such as mentally retarded children who need communication like children in general. His developmental delays are often excluded from his playing enviranment, thus the need for good social interaction with mentally retarded children. Based on these problems, a study was conducted to describe the findings of social interaction in mentally retarded children in extraordinary school Mentari Kita. The research is a descriptive analysis with qualitative research approach. Technique of data analysis was performed with data reduction stage, the presentation of data, and verification (conclusions). Researchers used the test of credibility, transferabilitas, dependabilitas, and konfirmabilitas to obtain the validity of the data. The result showed that the way social interaction with mental retardation children how do social contacts and communication as being able to respond when invited to communicate but it should be repeated over and over,the subject has a weakness in the concentration of so when invited to talk hard staring at your opponent's interlocutor. When did the subject communication using language that sounds stilted. Social contact subject well againts his peers is characterized by sensitivity to her friends when in distress, want to help his friend like get a pencil, and divide the food per day taken by subject. Based on the above research result it can be concluded that the way the social interactions of the child with mental retardation how do social contacts and communication in accordance with the terms of the occurrence of social interaction.
\end{abstract}

Keywords: Social Interaction, Mental Retardation

\section{INTRODUCTION}

Education is the most important factor and a top priority that requires serious attention from all parties, because education is a determinant of the nation's progress in the future[1]. National goals and ideals, for the intellectual life of the nation is contained in the 1945 Constitution. The government together with the community continues to seek the development of education for the realization of an independent, superior and ready nation to face the globalization world [2]

Learning for children with special needs (Student With Special Needs) requires a separate pattern according to their individual needs. The different characteristics of each student with special needs will require the ability of the teacher to combine various abilities and talents of each child in several aspects including the ability to think, see, hear, and how to socialize. A teacher's proficiency in aligning the existence of his students with the existing curriculum, then mixed into an individual learning program.

Parenting is a habit that is usually done by fathers and mothers that are applied to children in their development [3]. Social interaction plays an important role in the moral development of children. Social interaction makes children learn to be responsible and cooperate with friends and group members, and learn to get along and adapt to the environment to evoke understanding of the surrounding environment. Humans are social beings who cannot live alone without help from others.

Mental retardation or mental retardation is a term used to refer to children whose intelligence development experiences obstacles so they do not reach the optimal development stage, where their IQ level is 51-36 on the Binet Scale and 54-40 according to the Weschler Scale (WISC). The human body has billions of cells that have a central genetic information on the chromosome. Mentally retarded children are often excluded from their playing environment, the delay in their development makes their peers "reluctant" to play with them. They also often get discriminatory behavior because of the different abilities they have. Thus the need for good social interaction for mentally retarded children.

Children with mental retardation need communication like children in general. Communication is needed to interact with the environment, one form of communication that is speaking of mentally retarded children requires maximum attention to adjust to their environment, cooperate with others and evoke understanding with the surrounding environment. Speech is a physical characteristic of mentally retarded children where the uterus experienced by mentally 
retarded children is large, thick lips, narrow nasal cavity, and imperfect jaw position causes prominent articulation disorders so that it will be difficult to communicate with the surrounding environment.

Based on observations made by researchers at the extraordinary school Mentari Kita in Bogor City. Observations were conducted by researchers in class IV. Children with mild intellectual disabilities will be used as research subjects. Generally children with mental retardation have difficulty interacting socially with their environment. When in the school environment there are some problems that occur in children's social interactions. The researcher saw the subject able to interact with his environment even though it was not as maximal as other normal children. In contrast to children with other mental disabilities who are not at all able to interact socially with their environment.

The formulation of the problem in this study is how is the way of social interaction of mentally retarded children in Class IV of the the extraordinary school Mentari Kita in Bogor City?

Social interaction is one way humans interact, talk, communicate with people and groups with groups, groups with individuals, with the existence of social interaction humans can learn and understand the actions of individuals and other social groups.

Santoso's opinion [4] suggests that social interaction is one way for individuals to maintain the individual's social behavior so that individuals can still behave socially with other individuals. Social interaction can also increase the quantity / quality and quality / quality of social behavior with other individuals in social situations. Based on Lestari [5] that social interaction is dynamic social relationships that involve people's relationships between human groups. In interacting an individual or social group is trying or learning to understand the social actions of an individual or other social group.

Based on Setiadi [6] that the conditions for the occurrence of social interactions are as follows: (1) the existence of social contacts. The word "contact" comes from the Latin con which means together and tanga which means touching. So literally contact means "touch together". As a social symptom of contact does not need to happen by touching each other, therefore people can hold relationships with other people without having to physically contact. For example, people talk by telephone, send news via mail, and so on. (2) communication. Someone gives an interpretation of the behavior or feelings of others in the form of speech, gestures, or certain attitudes.

While the opinion of Gerungan [7] that when a person or group of people starts social interaction in their lives, it will be faced with situations where a person or group of people interact and communicate with each other, this is called a social situation. Social situations according to the existence of action in interaction as a response given to the interlocutor and as a behavior that is shown by someone when interacting.

Based on Soekanto [8] that the ongoing process of social interaction is based on various factors, including: imitation factors, suggestion factors, and sympathy factors.

Furthermore Soekanto [8] that forms of social interaction can be in the form of cooperation (cooperation), competition (competition), and can even be in the form of conflict or conflict. A dispute might get a solution. Maybe the settlement will only be accepted for a while, called accommodation (accomodation); and this means that both parties do not necessarily fast completely. Keemoat the basic form of social interaction does not need to be a continuity, in the sense that the interaction began with cooperation which later became competition and culminated into a dispute to finally arrive at accommodation.

Based on the statements of the theories above, it can be synthesized that social interaction is in the form of reciprocity of people and groups influence each other in thoughts and actions. In social interaction there are two contradictory forms, namely associative social interaction, while social interactions that lead to resistance are called dissociative. This can not be separated from the condition of the occurrence of social interaction, namely the existence of communication and social contact. Social contacts occur between individuals with individuals, individuals with groups, and groups with groups. Social contact is the most important thing because of communication. Without communication, social interaction will not occur. From the problem above,

Children with special needs are children with special characteristics that are different from children in general without always showing mental, physical, emotional disabilities. Effendi [9] that the term subnormal mental disorder children from several references is also called mental retardation, memory weakness, feebleminded, mental subnormal, mental retardation. A person is categorized as a subnormal mental disorder or mental retardation, if he has such a low level of intelligence (below normal) that to pursue his developmental tasks requires specific assistance or services, including in his education program.

classification according to Sukmanasa [10] the classification of retardation that has long been known is debilitating, imbecile and idiots. Whereas the classification conducted by educators in America is educable mentally retarded, trainable mentally retarded and totally custodial dependent. The mentioned grouping has rarely been used because it has too much consideration of one's academic abilities. The classification currently used is as follows: 1) mild mental retardation (mental retardation 70-55, mild), 2) Moderate mental retardation (mental retardation is 5540, moderate), 3) Severe mental retardation (mental 
retardation) 40-25, severe) 4) Profound mental retardation (IQ impairment is 25 and below, very severe). The classification used in Indonesia, which is in accordance with PP 72 of 1991, is as follows: 1) Mild mental retardation of IQ 50-70, 2) Mentally retarded IQ of 30-50, 3) Heavy and very severe mental retardation IQ is less from 30 .

Every child has different characteristics from other children. Likewise children with special needs, especially mentally retarded children who have different characteristics with children in general. Hakim [11] that the characteristics of children with mental retardation are grouped into two, namely mental retardation in general and specifically mental retardation.

The causes of impairment are internal and external factors. The factors that cause mental retardation between children one and another are different. Opinions from Prabawati [12] regarding the causes of mental retardation, namely: 1) Endogoen factor, a) Factors of heredity (heredity) b) From the child itself, which is due to poisoning, anxiety, conflict that results in neurosis and psychosis. 2) Exogenous factors External factors include: a) Social factors of the community from the environment he is in, b) Nonsocial factors, namely the condition of climate, air, land, culture (natural environment).

Every child has the right and service they deserve, both normal children and children with special needs. Children with special needs have special educational services, which are different from other normal children. The education services they get are in accordance with their level of abnormality. Other opinions expressed by Yosiani [13] mentally retarded children need special education and special services that are different from children in general. There are several special education and services provided for mentally retarded children, namely: a) Transition Class, b) Special Schools, c) Integrated Education, d) Home School Program, e) Inclusive Education, f) Grievance Home

Based on the statements of the theories above, it can be synthesized that mentally retarded children have an intellectual capacity (IQ) below 70 which is accompanied by an inability to adjust to the environment, which is characterized by limited intelligence and incompetence in social interaction. Internal and external factors that cause tuberculosis so that the types of obstructions are classified.

\section{RESEARCH METHODS}

This study uses a type of qualitative research with a case study method. That is analyzing and describing the social interactions of mentally retarded children in the extraordinary school Mentari Kita, Bogor City. Sugiyono [14] qualitative research is research that is based on the philosophy of postpositivism, used to examine the condition of natural objects, where the researcher is a key instrument, and the results of qualitative research emphasize more meaning than generalization

In finding the correct data about the Social Interactions of Mentally Impaired Children in the extraordinary school Mentari Kita, Bogor City, researchers used data collection techniques through observation, interviews and documentation studies. In this study the data source was determined by purpose techniques. Sources of data in qualitative research are called informants. Sources of data from this study are students with mental retardation, close friends (peers), Class Facilitators (homeroom), Occupational Therapists.

Data analysis in qualitative research is carried out when data collection takes place, and after data collection in a certain period. Analysis of the data used in this study is in accordance with what was stated by Miles and Huberman in sugiyono [14] that data analysis carried out in qualitative research is through the process of data reduction, data presentation, and conclusions (verification).

\section{RESULTS AND DISCUSSION}

Data from research conducted in August. 2018. The data of this study were carried out interactively and continued continuously to completion so that the data obtained had met the saturation point. This data is obtained from the results of observations, interviews, and documentation.

Based on the analysis of the results of the research that has been done it can be concluded that the subject is able to say hello when entering the class even though only to Mrs. Hellen and Mr. Andre, the subject every day brings lunch to school even though only biscuits and subjects always share their friends and share the teacher. The subject plays in the classroom and outside the classroom with his friends like playing lego, playing puzzles, the subject is always escorted to school by his mother, the subject is able to look into the eyes of his interlocutor when communicating even if only for a few seconds.

The subject is able to shake hands when meeting someone he has just recognized, the subject likes to help his friends when in distress including the facilitator and his therapist such as picking up a pencil when a friend's pencil picks it up, erases the writing on the board, takes a marker for the facilitator, communicates the subject verbally and doing gestures to make it easier for the interlocutor to understand what the subject wants, for example when the subject invites his friend to play the subject tugging at his friend's hand and inviting him out, when the subject invites to speak the subject only touches the shoulder which will be invited to chat. 
Subjects make social contact and communication despite obstacles, the subject does not always depend on the therapist as the subject always does the task not halfway, the subject can help the therapist to do something, the potential possessed by the subject is better developed since the subject routinely follows therapeutic activities at school.

The main problem revealed in this study is to obtain an overview of the social interactions of mentally retarded children. As can be seen in the research findings that children with intellectual disabilities are able to interact socially, but still have difficulty maintaining attention, using good and correct vocabulary.

The subject saluted when entering the class even though only to Mrs. Hellen and Mr. Andre, the subject every day brought lunch to school even though only biscuits and subjects always divided their friends and divided the teacher. The subject plays in the classroom and outside the classroom with his friends like playing lego, playing puzzles, the subject is always escorted to school by his mother, the subject is able to look into the eyes of his interlocutor when communicating even if only for a few seconds. The subject is able to shake hands when meeting someone he has just recognized, the subject likes to help his friends when in distress including the facilitator and his therapist such as picking up a pencil when a friend's pencil picks it up, erases the writing on the board, takes a marker for the facilitator, communicates the subject verbally and doing gestures to make it easier for the interlocutor to understand what the subject wants, for example when the subject invites his friend to play the subject tugging at his friend's hand and inviting him out, when the subject invites to speak the subject only touches the shoulder which will be invited to chat.

There is one friend of the subject who often interferes with the emotions of the subject, Eza, the subject often fights with Eza because Eza is a child who is ignorant. At the time of learning, the subject is rather difficult to concentrate because the subject experiences low concentration, the subject must be given repeated instructions to follow what is ordered, the subject always tells new things to the facilitator and therapist, the subject is independent in doing the task no longer assisted by the facilitator, the subject always asks someone if they do not enter the class even though the subject speaks in a rigid language, the subject always asks what has been asked repeatedly. The subject responds to what is instructed by the facilitator but must be repeated by order due to the lack of concentration possessed by the subject so that the concentration is slightly disturbed. The subject always tells all of his experiences to the people closest to him. Subjects always follow the therapy held by the school namely occupational therapy. This occupational therapy aims to develop strength and coordination with or without tools.
The ability of the subject to interact very well, able to respond when invited to communicate but must repeatedly interact well in the learning process and outside the learning process. The subject has weaknesses in concentration so when invited to speak it is difficult to look into the eyes of the interlocutor. When communicating with subject facilitators using rigid-sounding language this is due to the subject having deficiencies in vocabulary vocabulary, according to Wardani et al. [12]. but language mastery is adequate in certain situations. The subject is able to play with his friends in class and outside the classroom, good subject social contact with his friends is characterized by sensitivity to his friends when in distress, willing to help his friend like picking a pencil, divide the food that the subject carries every day to eat at recess

\section{CONCLUSION}

Based on the findings of research in the field regarding the social interaction of mentally retarded children, it can be concluded that social interaction is not something that cannot be done by children with mental retardation. Mentally retarded children are able to interact even though they only touch each other, they are able to interact even though the sentence is still not neatly arranged and tends to sound stiff, he lacks communication in verbal terms, which he communicates by doing gestures. how to interact socially with good social contact and communication, such as being able to respond when invited to communicate, but must repeatedly interact well in the learning process and outside the learning process. The subject has weaknesses in concentration so when invited to speak it is difficult to look into the eyes of the interlocutor. When communicating with the subject facilitator using a language that sounds stiff because the subject has a deficiency in vocabulary vocabulary, the subject is able to play with friends in class and outside the classroom The subject always tells all of his experiences to the people closest to him.

A good subject social contact with his friends is characterized by sensitivity to his friends when in distress, wanting to help his friend like picking up a pencil, divide the food that the subject takes every day to eat in recess.

\section{REFERENCES}

[1] Y. Suchyadi and Nurjanah, "Relationship between Principal Supervision in Increasing the Job Satisfaction of Private Junior High School Teachers in East Bogor District," J. Humanit. Soc. Stud., vol. 02, no. 01, pp. 26-29, 2018.

[2] Y. Suchyadi, "Relationship between Work Motivation and Organizational Culture in 
Enhancing Professional Attitudes of Pakuan University Lecturers," vol. 01, no. 01, 2017.

[3] S. Setiarani and Y. Suchyadi, "Pola Asuh Orang Tua Terhadap Anak Tuna Netra Berprestasi," J. Pendidik. Pengajaran Guru Sekol. Dasar, vol. 01, no. 01, pp. 15-18, 2018.

[4] Santoso,Slamet. 2014. Teori-Teori Psikologi Sosial. Bandung: Refika Adhitama

[5] Lestari,I.P.2013. "Interaksi Sosial Komunitas Samin dengan Masyarakat Sekitar". Jurnal Komunitas.Vol.5,No.1

https://journal.unnes.ac.id/nju/index.php/komunit as/article/view/2376 diakses tanggal 26 Februari 2016

[6] Setiadi, M.E.Dan Hakam, A.K. Dan Effendi, R. 2017. Ilmu Sosial dan Budaya Dasar. Jakarta: Kencana

[7] Gerungan,W. 2012. Psikologi Sosial. Bandung: PT Refika Aditama

[8] Soekanto, Soerjono. 2012. Sosiologi Suatu Pengantar. Jakarta: Raja Grafindo Persada

[9] Effendi, M. 2008. Pengantar Psikopedagogik Anak Berkelainan. Jakarta: PT.Bumi Aksara

[10] Sukmanasa, Elly, dkk. 2017. Pengantar Pendidikan Anak Berkebutuhan Khusus. Bogor: Universitas Pakuan

[11] Hakim, R.A,dkk.2013. "Pengaruh Usia Dan Latihan Keseimbangan Terhadap Kemampuan Motorik Kasar Anak Tunagrahita Kelas Bawah Mampu Didik Sekolah Luar Biasa”. Journal Of Physical Education And Sports. Vol.2,No.1 https://scholar.google.com/citations?user=_JN37x sAAAAJ\&hl=id diakses tanggal 26 Februari 2018

[12] Prabawati, Feby. 2007. Studi Tentang Minat Anak $S L B / C$ terhadap pelajaran Ekztrakurikuler. Jakarta:Universitas Jakarta

[13] Yosiani, Novita. 2014. Relasi Karakteristik Anak Tunagrahita Dengan Pola Tata Ruang Belajar Di Sekolah Luar Biasa. E-Journal Graduate Unpar. Vol.1, No.2 http://journal.unpar.ac.id/index.php/ unpargraduate/issue/view/129 diakses tanggal 31 Oktober 2018

[14] Sugiyono. 2015. Metode Penelitian Pendidikan. Bandung:Alfabeta. 